\title{
ENHANCED PRODUCTION OF $\beta$ - GLUCOSIDASE BY LOCALLY ISOLATED FUNGAL STRAIN EMPLOYING SUBMERGED FERMENTATION
}

\author{
AUMENTO DA PRODUÇÃO DE $\beta$-GLUCOSIDASE POR ESTIRPE \\ FÚNGICA ISOLADA LOCALMENTE, POR FERMENTAÇÃO SUBMERSA
}

\author{
Roheena ABDULLAH ${ }^{1 *}$; Sobia NAZIR CHUDHARY ${ }^{1}$; Afshan KALEEM ${ }^{\mathbf{1}}$; \\ Mehwish IQTEDAR ${ }^{1}$; Kinza NISAR ${ }^{1}$; Tehreema IFTIKHAR ${ }^{2}$; Faiza SALEEM $^{1}$ \\ 1. Department of Biotechnology Lahore College for Women University, Lahore, Pakistan; 2. Department of Botany Lahore College \\ for Women University, Lahore, Pakistan. roheena_abdullah@yahoo.com
}

\begin{abstract}
: $\beta$-glucosidase has wide spectrum of biotechnological applications in different industries including food, textile, laundry detergents, pulp and paper, pharmaceutical and biofuel industry. The present investigation related to isolation, screening, and process optimization of fungal strain for enhanced production of $\beta$-glucosidase (BGL). For this purpose, different fungal stains were isolated from different sources including soil, fruits, bark of tree as well as from the compost. The screening of fungal strain for BGL production was carried out via submerged fermentation. All the tested strains were identified on the basis of micro and macroscopic features. The fungal strain having greater ability for BGL synthesis among tested ones was identified as Aspergillus niger and given the code SBT-15. The process parameter including fermentation media, temperature, $\mathrm{pH}$, rate of fermentation, carbon and nitrogen sources, volume of media were optimized. Five different fermentation media were evaluated M3 medium gave maximum production. The optimal conditions for BGL production was 72 hours of incubation at $40^{\circ} \mathrm{C}, \mathrm{pH} 6$ and $50 \mathrm{ml}$ fermentation medium. Glucose (1\%) and ammonium sulphate (3\%) were optimized as best carbon and nitrogen sources, respectively.
\end{abstract}

KEYWORDS: $\beta$-glucosidase. Aspergillus niger. Fungi. Submerged fermentation.

\section{INTRODUCTION}

$\beta$-glucosidase (E.C.3.2.1.21) is one of important enzyme of cellulases. It catalyzes the hydrolysis of $\beta-1,4$ glycosidic linkage in various disaccharides, oligosaccharides, alkyl, aryl beta-Dglucosides by acting upon non reducing ends and ultimately produces beta-D glucose (IWASHITA et al., 1999; WALLECHA ; MISHRA, 2003). $\beta$ glucosidase plays central role in the degradation of cellulose (SEIDLE et al., 2004). The enzymatic degradation of cellulose by cellulases occurs in successive reactions: endoglucanase and exoglucanase catalyzes conversion of cellulose into cellobiose and beta glucosidase then convert the cellobiose into free glucose molecule (SAJITH et al., 2016). $\beta$-glucosidase is typically used for regulation of full cellulolytic mechanism and known to be rate- limiting factor during enzyme hydrolysis of cellulose, as both endo-glucanases and exoglucanases are often restricted by cellobiose. Thus $\beta$-glucosidase not only biosynthesizes glucose but also minimizes cellobiose inhibition, allowing endo and exo-glucanases enzymes to be function more accurately (KAUR et al., 2007). $\beta$-glucosidases (BGL) can be obtained from different sources including plant, animal, bacteria and fungi. However, production of $\beta$-glucosidase from microbial sources is preferred over other sources due to their ability of fast growth and independence from seasonal fluctuations. Fungi is preferred over bacteria due to excretion of considerable amount of BGLs (RECZEY et al., 1996; SINGHANIA et al., 2006). Fungal $\beta$ glucosidases are more resistant to environmental harsh circumstances compared to bacteria (DAMISA et al., 2011). In addition to this bacterial enzyme system is more complex, as compared to fungal enzymes. Fungal enzyme system is very simple consisting of two separate cellulose binding module (CBM) and catalytic domain (CD) (PANDEY, 2003; KUHAD et al., 2011). The fungi are potential source of $\beta$-glucosidases. The common fungi reported for production of $\beta$-glucosidases included A. niger, Phanerochaete chrysosporium, $P$. decumbens, Penicillium brasilianum, A. oryzae, Talaromyces emersonii, and Thermoascus aurantiacus (OKSANEN et al., 2000; RANI et al., 2015).

$\beta$-glucosidase have myriad industrial applications such as in processing of food items, 
Enhanced production...

used in textile wet processing and finishing of cellulase based textile, in paper and pulp industry for refining woody based pulp to obtain paper. In spite of this it play vital role in oil extraction improvement, treatment of waste materials, and in bioethanol production (RAJOKA, 2004; SINGHANIA et al., 2013). $\beta$-glucosidase are also used in release of aromatic compounds from glycosidic precursors already present in fruit juices, musts, wines (GUEGUEN et al., 1998). $\beta$ glucosidases are used in broad range of biotechnological pathways such as in making enzymes with huge hydrolyzing activity to heat tolerance, acid resilience, and in feasible transglycosylase action (KRISCH et al., 2010).

$\beta$-glucosidases can be produced employing solid state and submerged fermentation techniques. SMF technique gives several benefits over solid state fermentation such as possibility of automation of several operations, different parameters can be monitored easily (using periodic sampling of liquid media), easy to control whenever addition of nutrients and reagents is required and in large fermenter heat generated by microbial growth can be easily removed (JAKUBIKOVA et al., 2006). In submerged fermentation techniques products are directly excreted in broth and can be recovered easily (GÜNATA ; VALLIER, 1999). Although optimization of different parameters is challenging task towards establishment of successful enzyme production but it is very necessary for enhanced production of enzyme. The physico chemical elements play major role in the production of enzymes. The physico chemicals parameters play significant role is named $\mathrm{pH}$, Temperature, and rate of fermentation (GOKHALE et al., 2011). The objective of this study was to isolate fungal strain having $\beta$-glucosidase potential and optimization of conditions for enhanced production of desired enzyme.

\section{MATERIAL AND METHODS}

\section{Isolation of fungal strain}

Isolation of different fungal strains was carried from different sources including dung of animals, bark of tree, fruits and soils collected from different locations of Punjab Pakistan. The isolation of fungal strain was performed using serial dilution process (CLARK et al., 1958). All the isolated strains were screened via submerged fermentation in order to find out the BGL potential.

\section{Fungal Wet Mount technique}

Microscopic characteristics of fungi were
ABDULLAH, R. et al.

determined using wet mount technique through suspension of culture in water, mixed with alkali to dissolve background material. Methylene Blue was used as mounting medium. A small amount of fungal specimen was placed in a drop of methylene on a clean slide. The coverslip was placed and the slide was observed under the microscope for the morphological characteristics of fungi (SANGEETHA; THANGADURAI, 2013).

\section{Pretreatment of Substrate}

The sample of sugar cane bagasse was chopped into small pieces and sun dried. Pretreatment of sugar cane bagasse was carried by dipping in $4 \%$ solution of sodium hydroxide for 24 h. After this washed the sample with distilled water and dried in oven at $60{ }^{\circ} \mathrm{C}$ for $3-4 \mathrm{~h}$ (HAQ et al., 2006).

\section{Inoculum preparation}

The homogenous suspension of spore/conidia was prepared by adding $10 \mathrm{ml}$ of saline water in 3-4 days old fungal culture and mixing them with the help of inoculating loop and shaking the test tube vigorously.

\section{Submerged fermentation technique}

The $250 \mathrm{ml}$ Erlenmeyer flask containing $100 \mathrm{ml}$ of sterilized medium was inoculated with $1 \mathrm{ml}$ of conidial/spore inoculum under aseptic conditions. All the flasks were incubated at $40{ }^{\circ} \mathrm{C}$ in a shaking incubator. After a fixed period of interval fermented broth was centrifuged at $6000 \mathrm{rpm}$ for 15 min. The supernatant obtained was used to estimate $\beta$-glucosidae. All the experiments were carried out in triplicates.

\section{Fermentation Media}

Following media were screened for production of $\beta$-glucosidase. The components in media are present in $\left(\mathrm{g} \mathrm{L}^{-1}\right)$

M1: The medium containing $\mathrm{g} \mathrm{L}^{-1}\left(\mathrm{NH}_{4}\right)_{2} \mathrm{SO}_{4}$ 1.4, $\mathrm{KH}_{2} \mathrm{PO}_{4}$ 2.0, Urea 0.3, $\mathrm{MgSO}_{4} 7 \mathrm{H}_{2} \mathrm{O} 0.3, \mathrm{CaCl}_{3} 0.3$ $\mathrm{FeSO}_{4} .7 \mathrm{H}_{2} \mathrm{O} 0.005, \mathrm{ZnSO} .7 \mathrm{H}_{2} \mathrm{O} 0.0014, \mathrm{MnSO}_{4} \mathrm{H}_{2} \mathrm{O}$ $0.0016, \mathrm{COCl} 3$ 0.002, Tween $802.0 \mathrm{ml}$, Carboxy methylcellulose 10.0 as substrate (OKONKWO et al., 2014)

M2: $\quad\left(\mathrm{NH}_{4}\right)_{2} \mathrm{SO}_{4} \quad 0.5, \quad \mathrm{KCl} \quad 1.0, \quad \mathrm{KH}_{2} \mathrm{PO}_{4} \quad 0.5$, $\mathrm{MgSO}_{4} .7 \mathrm{H}_{2} \mathrm{O} \quad 0.2$, L-asparagine $0.5, \mathrm{CaCl}_{2} \quad 0.1$, yeast extract 0.5 with glucose $1 \mathrm{~g}$ as carbon source (EGGINS; PUGH, 1962)

M3: $\left(\mathrm{NH}_{4}\right)_{2} \mathrm{SO}_{4} 1.4, \mathrm{KH}_{2} \mathrm{PO}_{4} 2.0, \mathrm{MgSO}_{4} 7 \mathrm{H}_{2} \mathrm{O} 0.3$, $\mathrm{CaCl}_{2} \quad 0.3 \mathrm{~g}, \quad \mathrm{FeSO}_{4 .-} 7 \mathrm{H}_{2} \mathrm{O} \quad 0.005, \quad \mathrm{ZnSO}_{4 .} . \mathrm{H}_{2} \mathrm{O}$ $0.0014, \mathrm{MnSO}_{4} 0.0016, \mathrm{COCl}_{2}$ 0.002, peptone 10 , Sugarcane bagasse 10 (IRFAN et al., 2010). 
Enhanced production...

M4: Wheat bran and sugar cane bagasse $10 \mathrm{~g}$ each, $\left(\mathrm{NH}_{4}\right)_{2} \mathrm{SO}_{4}, \quad 3.5, \quad \mathrm{KH}_{2} \mathrm{PO}_{4} 3.0, \quad \mathrm{MgSO}_{4} \cdot 7 \mathrm{H}_{2} \mathrm{O} ; 0.5$ $\mathrm{CaCl}_{2} 0.5$, $1 \mathrm{ml}$ Tween 80 (DE-SOUZA et al., 2016).

M5: Urea 0.3, (NH4) ${ }_{2} \mathrm{SO}_{4} 1.4, \mathrm{KH}_{2} \mathrm{PO}_{4} 2.0$, $\mathrm{CaCl} 20.3, \mathrm{MgSO}_{4} \cdot \mathrm{H}_{2} \mathrm{O} 0.3$, peptone 1.0, $\mathrm{FeSO}_{4} \cdot \mathrm{H}_{2} \mathrm{O} 0.005, \mathrm{MnSO}_{4} \cdot \mathrm{H}_{2} \mathrm{O} 0.0016, \mathrm{ZnSO}_{4} \cdot \mathrm{H}_{2} \mathrm{O}$ $0.0014, \mathrm{CoCl} 20.002$ and carboxymethylcellulose 10, Sawdust 10 (AKINYELE et al., 2013).

\section{Enzyme Assay}

$\beta$-glucosidase estimation was carried out according to RAJOKA ; MALIK, (1997) $0.2 \mathrm{ml}$ PNPG $(10 \mathrm{Mm})$ along with $0.2 \mathrm{ml}$ crude enzyme and $0.6 \mathrm{ml}$ acetate buffer of $\mathrm{pH} 5(0.2 \mathrm{M})$ was added in a test tube. The test tube containing enzyme substrate mixture was incubated at $45^{\circ} \mathrm{C}$ for $10 \mathrm{~min}$. A blank was also run parallel. After incubation $3 \mathrm{ml}$ $\mathrm{Na}_{2} \mathrm{CO}_{3}(1 \mathrm{M})$ was added in all the test tubes to stop the reaction. The absorbance was measured at 400 $\mathrm{nm}$ using spectrophotometer. Paranitrophenol was used as standard. One unit of $\beta$-glucosidase activity was defined as "the quantity of enzyme required to liberate $1 \mu \mathrm{mol}$ of $p$-nitrophenol from substrate ( $p$ nitrophenyl- $\beta$-D-glucopyranoside)".

\section{Estimation of total protein contents}

Total protein contents were estimated according to BRADFORD method (1976).

\section{Estimation of dry cell mass (DCM)}

Dry cell mass was estimated according to IRFAN et al. (2010).

\section{Statistical Analysis}

All the experimental data was tabulated analyzed statistically using one way analysis of variance (ANOVA). The significance has been presented at $\mathrm{p} \leq 0.05$ by using SPSS (17.0).

\section{RESULTS AND DISCUSSION}

Isolation, screening and selection of fungi having greater ability to produce $\beta$-glucosidase are fundamental and most important steps for successful fermentation process. Fifteen different fungal strains capable for production of $\beta$-glucosidase were isolated. All the strains were screened and identified on the basis of macro and microscopic features. The quantitative screening was performed via submerged fermentation (data not shown). SBT-15 showed maximal $\beta$-glucosidase potential (0.93 IU $\mathrm{ml}^{-1}$ ) as compared to other isolates and identified as Aspergillus niger ( KLICH, 2002). Fermentation media plays vital role for carrying out successful fermentation process. Five different fermentation media were screened. Among these fermentation media M3 medium showed maximal $\beta$-glucosidase production (3.92 $\mathrm{IU} \mathrm{ml}^{-1}$ ) with total protein concentration 0.52 in contrast to other media (Fig 1). The reason might be that media contained pretreated sugarcane bagasse. Alkaline treatment play important role in delignification and increase the cellulose content of substrate and made the biomass easily accessible for microbial attack; which convert cellulose in to simple sugar and favoured fungal growth (IRFAN et al., 2010).



Figure 1. Influence of media on the production of $\beta$-glucosidase

The impact of varying incubation period ranging from $0-120 \mathrm{~h}$ on $\beta$-glucosidase production by Aspergillus niger SBT- 15 was evaluated (Fig. 2a). The enzyme reached peak of its activity (3.93 $\mathrm{IU} \mathrm{ml}{ }^{-1}$ ) at 72 hours, any rise in incubation time period resulted reduction in enzyme productivity. The depletion of nutrients in the fermentation medium or production of harmful byproducts and proteolysis of enzyme could be major reason for reduction of enzyme productivity. Our findings are 
Enhanced production...

similar to Raza et al. (2011) who reported $72 \mathrm{~h}$ is optimal time for $\beta$-glucosidase production when mix culture of $A$. niger and $A$.oryzae was used.

Variation in incubation temperature significantly affects enzyme production rate. Effect of varying incubation temperature ranging from 30 ${ }^{\circ} \mathrm{C}-60^{\circ} \mathrm{C}$ on $\beta$-glucosidase production by Aspergillus niger SBT-15 was tested (Fig 2b). It was noted that highest enzymatic activity $\left(3.95 \mathrm{IU} \mathrm{ml}^{-1}\right)$ was observed at $40{ }^{\circ} \mathrm{C}$. Decrease in enzymatic activity was observed at increasing temperature and it might be due to phenomenon of thermal instability of enzyme commonly observed in fungi at elevated temperature (TONG; COLE, 1982).

The volume of medium has paramount importance for the growth of microorganism as well as production of enzyme. Figure $2 \mathrm{c}$ shows influence of different volume of fermentation medium ranging from $25 \mathrm{ml}$ to $150 \mathrm{ml}$ on $\beta$-glucosidase production by Aspergillus niger SBT-15. Out of all tested volume maximum enzyme productivity $\left(5.55 \mathrm{IU} \mathrm{ml}^{-}\right.$ $\left.{ }^{1}\right)$ was observed in $50 \mathrm{ml}$ medium volume Decrease or increase in volume of medium from $50 \mathrm{ml}$
ABDULLAH, R. et al.

resulted decline in enzyme production. This could be increased volume of medium results reduction in agitation and recirculation of media ingredients which in turn results in decrease supply of nutrients to organisms and hence less enzyme production (WANG et al. 2008).

Another prevailing physical factor effecting synthesis of enzyme is $\mathrm{pH}$. The impact of variation in the $\mathrm{pH}(3-10)$ on the production of $\beta$-glucosidase was tested (Fig $2 \mathrm{~d}$ ). The maximum production of $\beta$ glucosidase $\left(6.38 \mathrm{IU} \mathrm{ml}^{-1}\right)$ was obtained when $\mathrm{pH} 6$ was used. Any Variation from optimal pH 6 resulted decrease in enzyme production. It might be due to slightly acidic $\mathrm{pH}$ value facilitates production of enzyme. Our findings are similar to SHATA et al. (2014) who reported optimal $\beta$-glucosidase activity was obtained at $\mathrm{pH} 6$ when $T$. reesei and A. oryzae mix culture was used. It is reported by many researcher that maximal productivity of enzyme was obtained in $\mathrm{pH}$ range between 5 -6 (LYND et al., 2002). At higher $\mathrm{pH}$ value less enzyme production might be due to proteolytic inactivation (ALI ; ELDEIN, 2008).

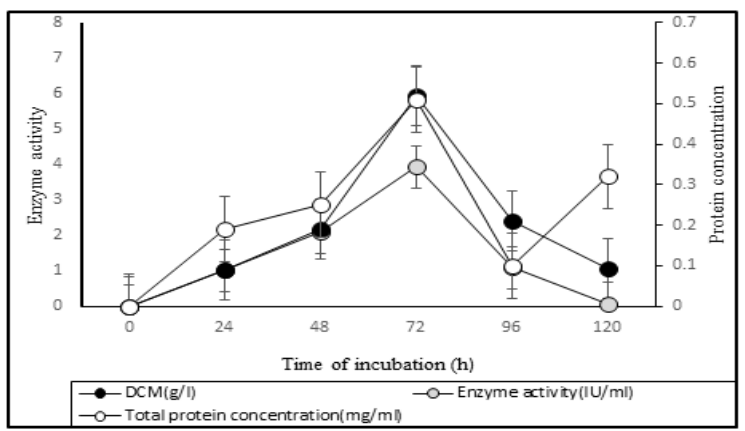

a

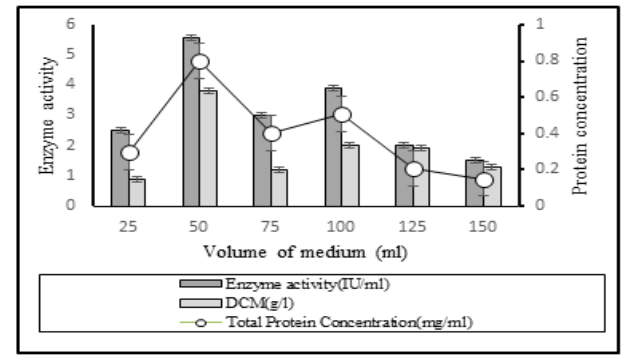

c

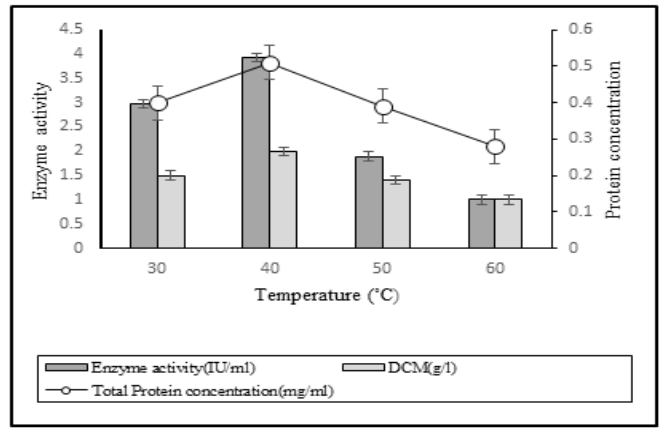

b

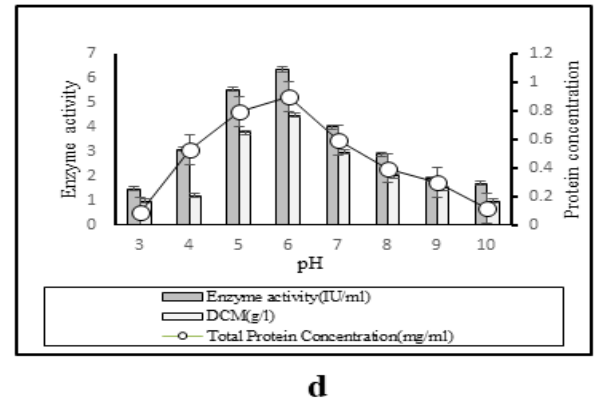

Figure 2. Effect of different physical parameters on the production of $\beta$-glucosidase (a) incubation time (b)

Enzyme production is significantly enhanced by presence of carbon sources in media. The effect of different carbon sources such as glucose, sucrose, xylose, lactose, fructose and maltose on the production of $\beta$-glucosidase production by Aspergillus niger SBT-17 employing submerged fermentation was tested (Fig. 3a). The maximal $\beta$-glucosidase productivity was obtained in the presence of glucose as additional carbon source. It might be due to inducing effect of glucose to produce highest enzyme when compared with other carbon sources (KANDARI et al., 2017). After selection of glucose as a best carbon source for $\beta$ glucosidase production different glucose concentration ranging from $(0.5-4 \%)$ was screened 
Enhanced production...

(Fig. 3b). Glucose at 1\% level gave maximal
ABDULLAH, R. et al. enzyme production $\left(8 \mathrm{IU} \mathrm{ml}^{-1}\right)$.

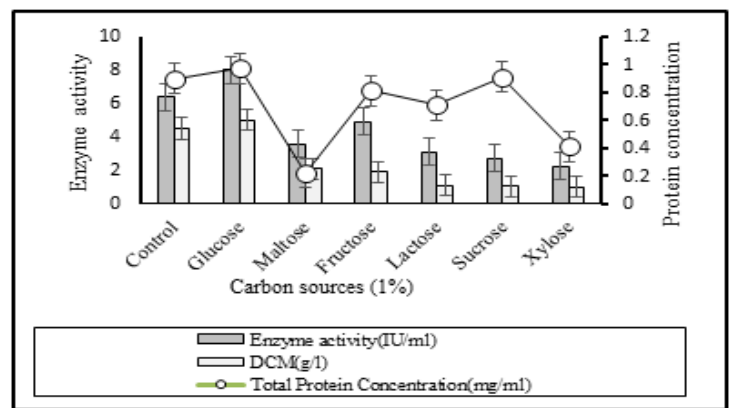

a

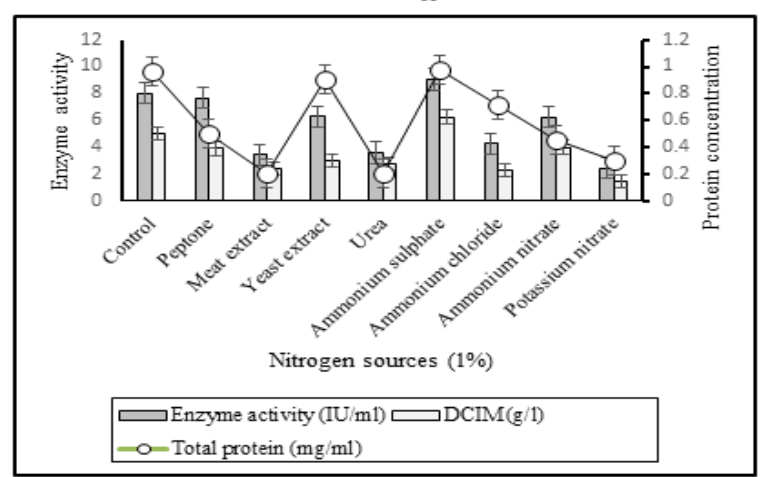

c

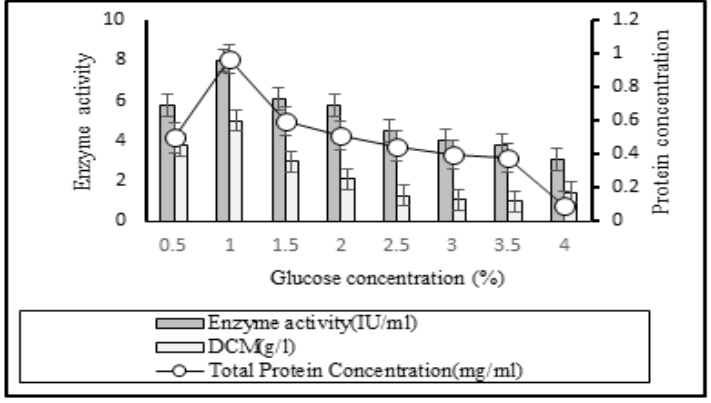

b

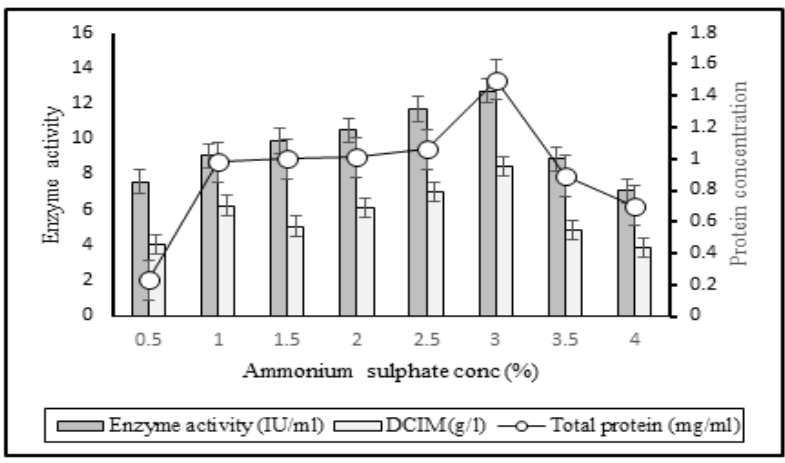

d

Figure 3. Effect of different nutritional parameters on the production of $\beta$-glucosidase (a) Carbon sources (b) Glucose concentration (c) Nitrogen sources (d) Concentration of ammonium sulphate

The effect of different nitrogen sources on the enzyme productivity was quite different depending upon the type of strain and concentration of nitrogen sources (KACHISHVILI et al., 2006). Different nitrogen sources like peptone, yeast extract, meat extract, urea, ammonium suphate, ammonium nitrate, potassium nitrate and ammonium chloride were screened out for biosynthesis of $\beta$-glucosidase by A. niger SBT-15 employing submerged fermentation (Fig. 3a). Ammonium sulphate gave optimal productivity of $\beta$-glucosidase. So different concentration of ammonium sulphate (0.5 to $4 \%$ ) was screened (Fig. $3 \mathrm{~d})$ and $3 \%$ concentration found to be optimum $\left(12.70 \mathrm{IU} \mathrm{ml}^{-1}\right)$. This could be due to the reason that inorganic nitrogen sources like ammonium are easily assimilated by fungal strain in contrast to organic nitrogen sources. Our findings are in line with Zahan et al. (2017) and Vidya et al. (2014) who reported ammonium suphlate is best nitrogen source for $\beta$-glucosidase production. The reduction in enzyme activity in the presence of other nitrogen sources is due to inhibitory effect on $\beta$-glucosidase production.

RESUMO: A $\beta$-glicosidase possui amplo espectro de aplicações biotecnológicas em diferentes indústrias, incluindo alimentos, têxteis, detergentes para lavanderia, papel e celulose, indústria farmacêutica e de biocombustíveis, etc. A presente investigação relaciona-se ao isolamento e triagem e otimização de processos de cepas fúngicas para produção aumentada de $\beta$-glucosidase (BGL). Para este efeito, diferentes manchas fúngicas foram isoladas a partir de diferentes fontes, incluindo solo, frutos, casca de árvore, bem como a partir do composto. A triagem da linhagem fúngica para produção de BGL foi realizada via fermentação submersa. Todas as cepas testadas foram identificadas com base em características micro e macroscópicas. A linhagem fúngica com maior capacidade de síntese de BGL entre os testados foi identificada como Aspergillus niger e recebeu o código SBT-15. O parâmetro do processo, incluindo meios de fermentação, temperatura, $\mathrm{pH}$, taxa de fermentação, fontes de carbono e nitrogênio, volume de mídia foram otimizados. Cinco meios de fermentação diferentes foram avaliados. O meio M3 deu a produção máxima. As condições ótimas para a produção de BGL foram 72 horas de incubação a $40^{\circ} \mathrm{C}, \mathrm{pH} 6$ e $50 \mathrm{ml}$ de meio de fermentação. Glicose (1\%) e sulfato de amônio (3\%) foram otimizados como melhores fontes de carbono e nitrogênio, respectivamente. 
PALAVRAS-CHAVE: $\beta$-glucosidase. Aspergillus niger. Fungos. Fermentação submersa.

\section{REFERENCES}

AKINYELE, J. B.; FABUNMI, A. O.; OLANIYI, O. O. Effect of variations in growth parameters on cellulase activity of Trichoderma viride NSPR006 cultured on different wood-dusts. Malaysian Journal of Microbiology, v. 9, n. 3, p. 193-200, 2013. https://doi.org/10.21161/mjm.47812

ALI, U. F.; EL-DEIN, H. S. S. Production and partial purification of cellulase complex by Aspergillus niger and A. nidulans grown on water hyacinth blend. Journal of Applied Sciences and Research, v. 4, n. 7. p. 875-891, 2008.

BRADFORD, M. M. A rapid and sensitive method for the quantitation of microgram quantities of protein utilizing the principle of protein dye binding. Analytical Biochemistry, v. 72 n. 2, p. 248-254, 1976. https://doi.org/10.1006/abio.1976.9999

CLARK, H., GELDRICH, E., KABLER, P. AND HUFF, C. Applied Microbiology, $\mathbf{1}^{\text {st }}$ ed. International Book Company, New York. p. 27-53, 1958.

DAMISA, D.; AMEH, J.; EGBE, N. Cellulase production by native Aspergillus niger obtained from soil environments. Fermentation Technology and Bioengineering, v. 1, p. 62-70, 2011.

DE-SOUZA, V. C. T; AMANDA, L. S. C.; RAFAEL, S. C.; MARCELLO, B. S. N.; GOMES, E. B. R.; GUSTAVO, O. Effect of $\mathrm{pH}$, Temperature, and chemicals on the endoglucanases and $\beta$-glucosidases from the thermophilic fungus Myceliophthora heterothallica obtained by solid-state and submerged cultivation.

Biochemistry Research Iinternational, v. 2016 p. 1-9, 2016. https://doi.org/10.1155/2016/9781216

EGGINS, H. O. W.; PUGH, G. J. F. Isolation of cellulose decomposing fungi from the soil. Nature, v. 193, p. 94-96, 1962. https://doi.org/10.1038/193094a0

GOKHALE, D.; KHISTI, U.; BASTAWDE, K. hyper-production of ßeta-glucosidase and ßeta-xylosidase by Aspergillus niger NCIM 1207 in xylan containing media. BioResources, v. 6, n. 2, p. 2066-2076, 2011.

GUEGUEN, Y.; CHEMARDIN, P.; JANBON, G.; ARNAUD, A.; GALZY, P. Investigation of the $\beta$ glucosidases potentialities of yeast strains and application to bound aromatic terpenols liberation. Studies in Organic Chemistry, v. 53, p. 149-157, 1998. https://doi.org/10.1016/s0165-3253(98)80018-7

GÜNATA, Z.; VALLIER, M. J. Production of a highly glucose-tolerant extracellular $\beta$-glucosidase by three Aspergillus strains. Biotechnology Letters, v. 21, n. 3, p. 219-223, 1999.

HAQ, I.; JAVED, M.M.; KHAN, T.S. Sugar cane bagasse pretreatment: an attempt to enhance the production potential of cellulases by Humicola insolens TAS-13. Biokemistri, v. 18, p. 2, 2006.

https://doi.org/10.4314/biokem.v18i2.56396

IRFAN, M.; NADEEM, M.; SYED, Q.; BAIG, S. Submerged cultivation of Aspergillus niger on pretreated sugarcane bagasse. World Journal of Agricultural Sciences, v. 6, n. 4, p. 466-472, 2010.

IWASHITA, K.; NAGAHARA, T.; KIMURA, H.; TAKANO, M.; SHIMOI, H.; ITO, K. The bglA gene of Aspergillus kawachii encodes both extracellular and cell wall-bound $\beta$-glucosidases. Applied and Environmental Microbiology, v. 65 n. 12, p. 5546-5553, 1999.

JAKUBIKOVA, L.; FARKAŠ, V.; KOLAROVA, N. NEMCOVIČ, M. Conidiation of Trichoderma atroviride isolate during submerged cultivation in a laboratory stirred-tank fermenter. Folia Microbiologica, v. 5, n. 3, p. 209-213, 2006. https://doi.org/10.1007/bf02932124 
Enhanced production...

ABDULLAH, R. et al.

KACHLISHVILI. E.; PENNINCKX M.J.; TSIKLAURI, N.; ELISASHVILI, V. Effect of nitrogen sources on lignocellulolytic enzyme production by white rot basidiomycetes under solid state cultivation. World Journal of MicroBiology and Biotechnology , v. 22, n. 4; 391-397, 2006. https://doi.org/10.1007/s11274-005-9046-8

KANDARI, V.; VAJPAYEE, I.; KUMAR, D.; GUPTA, S. Cellulase and $\beta$-glucosidase production by Trichoderma viride and Aspergillus wentii in submerged fermentation utilizing pretreated lignocellulosic biomass. Journal of Microbiology and Biotechnology Research, v. 3, n. 5, p. 63-78, 2017.

KAUR, J.; CHADHA, B. S.; KUMAR, B. A.; KAUR, G.; SAINI, H. S. Purification and characterization of ßglucosidase from Melanocarpus specie. MTCC 3922. Electronic Journal of Biotechnology, v.10, n. 2, p. 260270, 2007. https://doi.org/10.2225/vol10-issue2-fulltext-4

KLICH, M. A. Biogeography of Aspergillus species in soil and litter. Mycologia,v. 94, n. 1, p. 21-27, 2002. https://doi.org/10.2307/3761842

KRISCH, J.; TAKÓ, M.; PAPP, T.; VÁGVÖLGYI, C. Characteristics and potential use of $\beta$-glucosidases from Zygomycetes. Current Research, Technology and Eeducation Topics in Applied Microbiology and Microbial Biotechnology, v. 2, p. 891-896, 2010.

KUHAD, R. C.; GUPTA, R.; SINGH, A. Microbial cellulases and their industrial applications. Enzyme Research, v. 2011: p. 10, 2011. https://doi.org/10.4061/2011/280696

LYND, L. R.; WEIMER, P. J.; VAN ZYL, W. H.; PRETORIUS, I. S. Microbial cellulose utilization: fundamentals and biotechnology. Microbiology and Molecular Biology Reviews, v. 66, n. 3, p. 506-577, 2002. https://doi.org/10.1128/mmbr.66.3.506-577.2002

OKONKWO, I.; ODIBO, F.; OBELE, C. Time course for cellulase enzyme production by Aspergillus Flavus using different organic nitrogen sources. Scientific Journal of Biological Sciences, v. 3, n. 2, p. 24-28, 2014.

OKSANEN, T.; PERE, J.; PAAVILAINEN, L.; BUCHERT, J.; VIIKARI, L. Treatment of recycled kraft pulps with Trichoderma reesei hemicellulases and cellulases. Journal of Biotechnology, v. 78, n. 1, p. 39-48, 2000. https://doi.org/10.1016/s0168-1656(99)00232-1

PANDEY, A. Solid-state fermentation. Biochemical Engineering Journal, v. 13, n. 2, p. 81-84, 2003.

RAJOKA, M. I. Influence of various fermentation variables on exo-glucanase production in Cellulomonas flavigena. Electronic Journal of Biotechnology, v. 7, n. 3, p. 7-8, 2004. https://doi.org/10.2225/vol7-issue3fulltext-2

RAJOKA, M. I.; MALIK, K. A. Cellulase production by Cellulomonas biazotea cultured in media containing different cellulosic substrates. Bioresource Technology,v. 59, n. 1, 21-27, 1997. https://doi.org/10.1016/s09608524(96)00136-8

RANI, V.; MOHANRAM, S.; TIWARI, R.; NAIN, L.; ARORA, A. Beta-glucosidase: key enzyme in determining efficiency of cellulase and biomass hydrolysis. Journal of Bioprocessing and Biotechniques, v. 5, n.1, p. 1, 2015. https://doi.org/10.4172/2155-9821.1000197

RAZA, F.; RAZA, N. A.; HAMEED, U.; HAQ, I, ; I. MARIAM. Solid state fermentation for the productionof $\beta$-glucosidase by co-culture of Aspergillus niger and A. oryzae. Pakistan Journal of Botany, v. 43, n. 1, p. 7583, 2011.

RECZEY, K.; SZENGYEL, Z.; EKLUND, R.; ZACCHI, G. Cellulase production by T. reesei. Bioresource Technology, v. 57, n. 1, p. 25-30, 1996. https://doi.org/10.1016/0960-8524(96)00038-7 
SAJITH, S.; PRIJI, P;, SREEDEVI, S.; BENJAMIN, S. An overview on fungal cellulases with an industrial perspective. Journal of Nutrition and Food Sciences, v. 6, p. 461, 2016.

SANGEETHA, J.;, THANGADURAI, D., Staining Techniques and Biochemical Methods for the Identification of Fungi. Laboratory Protocols in Fungal Biology. Springer, 2013, p. 237-257, 2013. https://doi.org/10.1007/978-1-4614-2356-0_19

SEIDLE, H. F.; MARTEN, I.; SHOSEYOV, O.; HUBER, R. E. Physical and kinetic properties of the family 3 $\beta$-glucosidase from Aspergillus niger which is important for cellulose breakdown. The Protein Journal, v. 23 n. 1, p. 11-23, 2004. https://doi.org/10.1023/b:jopc.0000016254.58189.2a

SHATAA, H. M. A.; AZZA M.; DEENB, N.; GALAL, A. M. N.; NAWWARC, A.; FARIDB, M. A $\beta$.glucosidase production by mixed culture using crude hemicellulose from rice straw black liquor and peat moss as an inert support. Egyptian Pharmaceutical Journal, v. 13, n. 2, p. 121-129, 2014.

https://doi.org/10.4103/1687-4315.147074

SINGHANIA, R. R.; PATEL, A. K.; SUKUMARAN, R. K.; LARROCHE, C.; PANDEY, A. Role and significance of beta-glucosidases in the hydrolysis of cellulose for bioethanol production. Bioresource Technology, v. 127, p. 500-507, 2013. https://doi.org/10.1016/j.biortech.2012.09.012

SINGHANIA, R. R.; SUKUMARAN, R. K.; PILLAI.; PREMA, P.; SZAKACS, G.; PANDEY, A. Solid-state fermentation of lignocellulosic substrates for cellulase production by Trichoderma reesei NRRL 11460. Indian Journal of Biotechnology, v. 5 n. 3, p. 332-336, 2006

TONG, C. C.; COLE, A. L. Cellulase production by the thermophilic fungus, Thermoascus aurantiacus. Pertanika, v. 5, n. 2, p. 255-262, 1982.

VIDYA, B.; PALANISWAMY, M.; GOPALAKRISHNAN, V. Screening and optimization of $\beta$-galactosidase from fungal strains by using agro residues. World Journal of Pharmacy and Science, v. 3, n. 6, p. 1809-1821, 2014.

WALLECHA, A.; MISHRA, S. Purification and characterization of two $\beta$-glucosidases from a thermo-tolerant yeast Pichia etchellsii. Biochimica et Biophysica Acta-Proteins and Proteomics, v. 1649, n. 1 ,p. 74-84, 2003.

WANG, Y.H.; FENG, J.T.; ZHANG, Q.; ZHANG, X. Optimization of fermentation condition for antibiotic production by Xenorhabdus nematophila with response surface methodology. Journal of Applied

Microbiology, v. 104, n. 3, 735-744, 2008. https://doi.org/10.1111/j.1365-2672.2007.03599.x

ZAHAN, P.; SUN, J.; WANG, F.; ZAHAN, L.; CHEN , J. Process optimization of $\beta$-glucosidase production by a mutant strain of Aspergillus niger C112. Bioresources, v. 12, n. 4, p. 8937-8952, 2017 